\title{
Analysis of Differences between INA CBG's Rates and Hospital Real Rates in Hemophilia Patients at RSUD Zainoel Abidin Banda Aceh
}

\author{
Sari Haslinur ${ }^{1}$, Irwan Saputra ${ }^{2}$, Dedy Syahrizal ${ }^{3}$, Bakhtiar ${ }^{4}$, Said Usman ${ }^{5}$ \\ ${ }^{1}$ Magister Program of Public Health, Faculty of Medicine, Universitas Syiah Kuala Banda Aceh, Indonesia. \\ ${ }^{2,5}$ Department of Public Health, Faculty of Medicine, Universitas Syiah Kuala Banda Aceh, Indonesia. \\ ${ }^{3}$ Department of Biochemistry, Faculty of Medicine, Universitas Syiah Kuala Banda Aceh, Indonesia. \\ ${ }^{4}$ Department of Pediatric, Faculty of Medicine, Universitas Syiah Kuala Banda Aceh, Indonesia. \\ Sarihaslinur86@gmail.com,iwanbulba@unsyiah.ac.id,dedysyahrizal@unsyiah.ac.id, \\ bakhtiar@unsyiah.ac.id,Saidusman@unsyiah.ac.id
}

\begin{abstract}
INA CBG's rate is system of health financing packages from government based on cased and hospital services. Real tariff are the actual costs incurred by hospitals service based to local governments. During this time there are differences between INA CBGs rated and hospital rates. Hemophilia is a high-cost disease paid by INA CBGs. The aim of this study was to analyze the differences of INA CBGs and real rates in Hemophilia Patients at RSUDZA Banda Aceh. The research used quantitative analyticmethod. Data collection was carried out by taking secondary data from visits of hemophilia patients at RSUDZA in January-Desember 2019. The study population was all hemophilia patients in RSUDZA in 2019 with purpousive random sample of 100 people. There was a significant difference between INA CBGs rated and hospital rates rates in Hemophilia Patients at RSUDZA Banda Aceh.which indicated by p-value 0,000. Differences between INA CBGs and real rates of hospital are Rp.-431.095.538 or $-25 \%$. Differences of INA CBGs rated dan real rates causes' hospital loss, but hospital needs to re-review the calculation of more efficient service cost to improve the quality of service.
\end{abstract}

Keywords

INACBGs, real rates, hemophilia

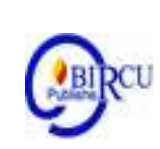

\section{Introduction}

INA-CBG system is one of the applications of government that is used as a filing of claims for hospitals, Public health center and all other health providers for the underprivileged in Indonesia. Case Bage Groups (CBG's), which is a method of paying for patient care based on relatively similar diagnoses or cases. The hospital will get payment by INA CBG's which is relatively the same and matches the average cost spent on treatment of a diagnosis. The initial purpose of this payment system is to carry out health service guarantees for the poor and underprivileged by using the principle of social health insurance (Nur Arif et al, 2013).

In accordance with the Regulation of the Minister of Health of the Republic of Indonesia Number 27 of 2014 concerning Health Service Standard Rates, it is stated that INA-CBG's is a "Package" payment system that is tailored to the illness suffered by patients. Then the Hospital will get a payment based on INA-CBG rates which are considered as the average cost to be spent on a diagnosis group (Doenges, E Marilynn, et al. 2000). Each disease diagnosis has INA-CBGS's rates that vary according to the average cost spent for the treatment of the diagnosis as a whole. 
One of the high-cost and life-threatening complications at INA-CBG's is a hemophilia. Hemophilia is a rare disease that causes bleeding disorders due to lack of blood clotting factors. As a result, bleeding lasts longer when the body is injured (Sudoyo, et al. 2007), but the disease is rarely recognized early on by the sufferer so that it often causes death, because only $10 \%$ of cases of hemophilia are detected early. Hemophilia sufferers on average from children to adults, do not know the age, race or gender according to their level and severity, mild, moderate or severe (Aru et al. 2009). The INA-CBG system sets a rate for hemophilia A level 1 cases of Rp. 17 million, for level 2 Rp. 21 Million and for level 3 Rp. 25 million and the costs will be different in each hemophilia A, B and C diagnosis group at each level.

Reviewing the previous years from 2014-2018, the number of hemophilia sufferers has increased every year, specifically in Aceh Province has increased significantly from 20142018, which was recorded in 2014 as many as 193 patients and increased dramatically in 2015 as many as 333 patients. In 2016 decreased to 224, then in 2017 again increased by 266 patients and the peak in 2018 were 332 patients.

Zainoel Abidin Hospital (RSUDZA) is a type A hospital located in Banda Aceh city area that has complete facilities and adequate services compared to other regional public hospitals in the Aceh region. RSUDZA is the only hospital in the Aceh region that provides care for hemophilia patients whose fees are paid by INA-CBG's in accordance with established standards and conditions (Rizki, Ismail. 2016).

From a preliminary study by researchers found several cases of hemophilia paid by the hospital an average of 25 million at one patient visit with a diagnosis of mild hemophilia, while INA-CBGs only bear 17 million only, it can be stated that there is a significant difference between costs hospital needs at a cost borne by INA CBGs. As noted by the data from Zainoel Abidin Hospital in Banda Aceh in December 2018, from 29 visits of level A (mild) hemophiliac patients, the average real hospital rate was Rp.746 million, while the average rate of INA-CBG's paid for the 29 visits was only Rp. 497 million alone, so this huge price difference is a serious problem for hospitals.

Based on this, the researcher would like to examine further the difference in costs between the INA CBGs tariff and the real hospital rate for Hemophilia cases in Banda Aceh Regional Hospital.

\section{Research Methods}

Research conducted using quantitative analytic methods. The variables in this study are the real hospital rates and INA CBGs rates for Hemophilia patients in RSUDZA, analysis of differences in real hospital rates and INA CBGs rates.

The population in this study was all hemophilia RSUDZA patients in JanuaryDecember 2019 who claimed with INA CBGs software as many as 440 patients. The numbers of samples in this study were 100 samples with a purposive random sample sampling technique.

The data used in this study are secondary data obtained from medical record files from the breakdown of treatment costs (billing) and data collection techniques by direct observation / observation by processing data using SPSS and Microsoft Excel. The analysis in this study used univariate, bivariate and thematic analysis. 


\section{Discussion}

\subsection{Research Results}

\section{a. Bivariate Analysis Results}

This analysis is carried out on two different variables to see the relationship that occurs between the Hospital Real Rates variable and the INA CBG Rates to see the difference between the two. Because the data obtained is not normally distributed, data analysis using the Man Whitney test.

Based on table 1, the sig value of the total hospital real rate and the INA CBG rate is pvalue 0,000 , which is smaller than the test significance value of 0.05 . These results indicate that the two variables have a very significant average difference between the two. It can be concluded that there is a significant difference between hospital rates and INA CBG rates on the care and treatment of hemophilia cases in RSUDZA Banda Aceh.

Table 1. Difference between INA CBGs Rates and Real Hospital Rates of Hemophilia Case in RSUDZA based on Levelity

\begin{tabular}{|c|c|c|c|c|c|}
\hline \multirow{2}{*}{$\begin{array}{c}\text { Hemofilia } \\
\text { Level }\end{array}$} & \multicolumn{2}{|c|}{ Rates } & \multirow{2}{*}{ Deviation } & \multirow{2}{*}{$\%$} & \multirow{2}{*}{ Sig. } \\
\hline & INA CBGs & Real Hospital & & & \\
\hline A & Rp1.371.158.600 & Rp1.659.433.247 & -Rp288.274.647 & -21 & 0,01 \\
\hline B & Rp64.656.000 & Rp68.106.198 & -Rp3.450.198 & -5 & 0,04 \\
\hline $\mathrm{C}$ & Rp291.888.100 & Rp481.860.793 & -Rp189.972.693 & -65 & 0,04 \\
\hline Total & Rp1.727.702.700 & Rp2.158.798.238 & -Rp431.095.538 & -25 & 0,000 \\
\hline
\end{tabular}

Based on the above calculation results, it is known that the total hospital rates issued for the treatment of patients with a diagnosis of hemophilia per levelity / severity as well as the total INA CBGs rates paid. The difference between INA CBG rates and hospital real rates on Hemophilia A is Rp. $(288,274,647)$ or $-21 \%$ with a significant value of 0.01 where there is a significant difference between the two, the difference in the cost of Hemophilia B in the amount of Rp. $(3,450,198)$ or $-5 \%$ with a value of sig. 0.48 where the difference is not too large, and the difference in the cost of Hemophilia C is Rp. $(189,972,693)$ or $-65 \%$ with a value of sig. 0.04 where the difference between the two rates is much different. The total difference between the hospital's real dance and INGS CBGS rates is Rp. $(431,095,538)$ or $25 \%$. The difference is negative because the total cost of treatment incurred by the hospital for hemophilia cases is greater than the total INA CBG rates paid by the health BPJS.

\section{b. Univariate Analysis Results}

Distribution of unit costs incurred for the treatment and treatment of hemophilia patients in Zainoel Abidin Regional Hospital Banda Aceh from January-December 2019

Table 2. Unit Costs incurred for the Treatment of Hemophilia Patients in RSUDZA Throughout 2019

\begin{tabular}{lcccc}
\hline \multicolumn{1}{c}{ Unit Cost Name } & $\begin{array}{c}\text { Total price } \\
(\mathbf{R p})\end{array}$ & $\begin{array}{c}\text { Number of } \\
\text { cases }\end{array}$ & $\begin{array}{c}\text { Average } \\
\text { Cost (Rp) }\end{array}$ & \% \\
\hline Non Surgical & 22.280 .100 & 86 & 222.801 & 1 \\
Procedure & 55.519 .950 & 22 & 555.200 & 2,6 \\
Surgical Procedure & 67.125 .000 & 100 & 671.250 & 3,1 \\
Consultant Physician &
\end{tabular}




\begin{tabular}{lcccc} 
Laboratory & 35.105 .500 & 25 & 351.055 & 1,6 \\
Blood Service & 48.960 .000 & 16 & 489.600 & 2,3 \\
Room & 112.800 .000 & 100 & 1.128 .000 & 5,2 \\
Medicines & 1.790 .541 .217 & 100 & 17.905 .412 & 82,9 \\
Medical devices & 1.142 .164 & 46 & 11.422 & 0,1 \\
BMHP & 25.324 .307 & 82 & 253.243 & 1,2 \\
\hline \multicolumn{1}{c}{ Total } & $\mathbf{2 . 1 5 8 . 7 9 8 . 2 3 8}$ & & \\
\hline
\end{tabular}

Table 2 shows the unit costs paid for hemophilia patients in RSUDZA, namely nonsurgical procedures, surgical procedures, consultant physician, laboratory, blood services, rooms, medicines, medical devices and BMHP (consumable medical items). From the table above it can be seen that the unit cost of medicines has the highest price of Rp.1,790,541,217 or $82.9 \%$ of the total costs while the smallest unit cost that costs the least in the treatment of patients with a diagnosis of hemophilia is the cost of Medical Devices (Alkes). Also obtained data on what medicines are used in hemophilia patients in RSUDZA namely Koate, Octanat and Octanine brands.

Table 3. Medicine Use Data for Hemophilia Patients in RSUDZA 2019

\begin{tabular}{cc}
\hline Medicine name & Number of patients \\
\hline Koate 250 & 6 \\
Koate 500 & 27 \\
Koate 1000 & 26 \\
Octanate 500 & 32 \\
Octanine 500 & 9 \\
\hline Total & $\mathbf{1 0 0}$ \\
\hline
\end{tabular}

Based on table 2, it can be seen that the medicine with the brand Octanate 500 which is the most widely used in the treatment of hemophilia is as many as 32 samples at a price of Rp. 2,090,000 per vial. Then the second order by the medicine brand Koate 500 with the use of 27 people at a price of Rp.3,375,900 per vialnya. Furthermore, the Koate 1000 brand of medicines with the use of 26 samples at a price of Rp.5,989,500 per vialnya. Then the Octanine 500 brand medicine with the use of 9 samples at a price of Rp.5,082,000 and the last order is the medicine brand Koate 250 as many as 6 samples with a price of Rp.1,063,750 per vialnya.

\subsection{Discussion}

a. Difference between Hospital Real Rates and Rates of INA CBGs

Based on the analysis of the test results of hemophilia patient visit data comparing the real hospital rates and the INA CBG rates in RSUDZA there are significant differences between the two (p-value 0,000) listed in table 1 . Besides that there is a difference in the mean (mean) rates real hospital costs $(2,158,798,238$, -) with INA CBG rates $(1,727,702,700$, -). Real hospital rates are calculated per breakdown of the types of services provided at RSUDZA where the standard tariff has been determined by Aceh's Governor Regulation Number 57 of 2013 concerning Service Fees at RSUDZA such as services, facilities and other medical services as needed. Whereas INA CBG rates are calculated based on costing data from the Indonesian Ministry of Health in accordance with the average hospital costs set by the government. 
The results of this study are similar to the study of Lili Suryani (2017) which states that there is a difference between the real hospital costs and the costs of INA CBGs for catastrophic cases with coronary heart disease in inpatients of JKN participants in RSUDZA. Lili Suryani (2017) states that the difference in costs is in line with the length of stay of the patient in the hospital, the longer the number of days of hospitalization, the higher the costs incurred so that the hospital suffers losses due to not all costs paid and can be covered by INA CBGs.

Based on the analysis of the data that has been done, it is known that the total hospital rates incurred for the treatment of hemophilia patients in RSUDZA is higher at Rp. $2,158,798,238$ while the total tariff for INA CBGs is Rp. 1,727,702,700. So the overall difference between the data collected from January to December 2019 is Rp. 431,095,538 or $25 \%$ of the INA CBGs tariff. The difference is negative because the total real hospital rates for hemophilia patients in RSUDZA are greater than the total INA CBGs paid by the health BPJS. From the explanation above, it is known that for the whole service for hemophilia patients from January to December 2019 the hospital suffered a loss with payment of INA CBGs of $25 \%$.

\section{b. Unit Cost that Costs the Most in the Treatment of Hemophilia Cases at RSUDZA}

From the results of data analysis that has been done, the difference in rates is due to several factors such as the length of stay patients in hospitals, medical equipment used, medical services and expensive hemophilia medicines so that from the INA CBGs could not cover the entire costs incurred and the cost gap occurred.

Table 2 explains the unit costs incurred for the treatment of hemophilia patients in RSUDZA which are the determinants of the high and low real hospital costs that must be spent, such as non-surgical procedures, surgical procedures, consultant physician, laboratory, blood services, rooms, medicines, medical devices and BMHP (consumable medical items). The unit cost is determined by the hospital itself as a standard of health care for the case handled. From the whole unit cost for each patient is different, each individual depends on the needs of patients during treatment, such as there are patients who need laboratory services or not, there are patients who need surgical procedures due to emergency cases and some are not, causing differences in costs which varies.

From these unit costs it is known that medicines are the most costly unit costs shown in table 2 where the unit cost of medicines has the highest graph compared to the others. This happens because the price of medicines for hemophilia patients is fairly expensive for onetime injection and hemophilia patients who need these medicines in large quantities and continue continuously until healed even for a lifetime. From table 2 it can be seen the types of medicines used for hemophilia patients in RSUDZA, namely Koate 250, Koate 500, Koate 1000, Octanate 500 and Octanine 500 whose prices per each vial are very expensive ranging between 2-5 million rupiah. The most widely used medicine is Octanate 500 because the number of hemophilia A patients (mild) with the use of Octanate 500 is more than other types of hemophilia in RSUDZA.

\section{Conclusion}

Based on the research conducted above, it can be concluded that there is a difference between real hospital rates and INA CBG rates in hemophilia cases in RSUDZA throughout 2019, where hospital real rates are greater than the INA CBGs tariff rates set by the Ministry of Health for hemophilia cases with the difference in tariffs reaching Rp.431,095,538, and the biggest cost paid from the entire cost of treatment is the cost of hemophilia medicines that are expensive for each individual patient so that the hospital seems to experience losses. 
However, it must be reviewed again to other costs in RSUDZA which are subsidized by the local government so that the hospital as a whole does not experience too much damage.

It is suggested to the RSUDZA management to reorganize hospital finances by conducting a review of the cost efficiency of cases with hospital rates that are sometimes greater than the INA CBGs rates so that hospitals do not experience large losses and can still improve the quality and quality of home services sick. It is hoped that further research will be able to find and apply hemophilia cases that are more efficient and cheaper to minimize costs in hemophilia cases because medicine costs are the biggest expense incurred in treating hemophilia cases in hospitals.

\section{References}

Adiama T. 2004. Manajemen Administrasi Rumah Sakit Edisi kedua. Jakarta: FK UI.

Adisasmito, D. W. 2008. Kebijakan Standar Pelayanan Medik dan Diagnosis Related Group (DRG), Kelayakan Penerapannya di Indonesia.

Adiwijaya, S., Aritonang, D. V. A., and Mashud, M. 2018. Empowerment Pattern for Thalasemi Patients in Dr. Soetomo Hospital Surabaya. Budapest International Research and Critics Institute-Journal (BIRCI-Journal) (1): 289-298.

BPJS, Pedoman Pelaksanaan Jaminan Kesehatan Nasional (JKN), Jakarta: Centers for Desease Control and Prevention (CDC.Gov). Hemophilia Treatment. 2019.

Firmansyah, T. 2014. Analisis Selisih Tarif RS Dengan Tarif INA-CBG

Fitri, D. 2014. Analisis Perbedaan Rata-Rata Biaya dan Mutu Pelayanan

Gani, A. 2006. Analisis Biaya Rumah Sakit Makalah Seri Manajemen Keuangan Pelayanan Kesehatan, Jakarta

Hoffard, A.V. 2005. Hematologi: Edisi IV. Jakarta: EGC

Intersains, I. D. 2016. Koate, Octanine dan Octanate. Jakarta, Indonesia Revisi May 2016. Manufactured by : Grifols Therapeutic Inc. USA

Kementrian Kesehatan Republik Indonesia. 2014. Peraturan Menteri Kesehatan Republik Indonesia Nomor 27 Tahun 2014 Tentang Petunjuk Teknis Sistem Indonesian Case Base Groups (INA-CBG's). Jakarta.

Made, A. and Wijaya. 2017. Perbedaan Tarif Riil dan INA CBGs Penyakit Thalasemia di Ruang Perawatan Anak RSUP Sanglah Bali Tahun 2017. Bali

Medidata, Referensi Obat MIMS. Edisi 2018. Jakarta: BIP

Padmawati, N. 2014. Analisis Perbandingan Antara Biaya Pelayanan Pasien Rawat Jalan dan Rawat Inap Berdasarkan Tarif Rumah Sakit Dengan Tarif INA_CBG Pada Program Jaminan Kesehatan Nasional Di RSU Zahirah Bulan Pelayanan Januari Hingga Mei 2014, Skripsi, Depok.

Peratuaran Menteri Kesehatan No 76 Tahun 2016 tentang Pedoman INA CBGs dalam Pelaksanaan Jaminan Kesehatan Nasional. Jakarta

Pradata, Y, I., Sarungu, J. J., and Suryantoro, A. 2020. Determinants of Savings and Community Loans in Ngawi District, 2010 - 2018 A Macro Economic Approach. Budapest International Research and Critics Institute-Journal (BIRCI-Journal) (3): 1506-1517.

Reliance, Sylvia, P. 2010. Hemofilia- Patofosiologis Klinis dan Proses Penyakit. Volume 1. Jakarta Rizki, Ismail. 2016. Profil RSUDZA Banda Aceh RSU Zainoel Abidin. FK UNSYIAH.

Suryani, L. 2017. Perbedaan Biaya Riil Rumah Sakit dan Tarif INA CBGs Untuk Kasus Katastropik dengan Penyakit Jantung Koroner Pada Pasien Rawat Inap Peserta Jaminan Kesehatan Nasional di RSUDZA. Banda Aceh: Jukema. Vol 3(1):198-205.

World Federation of Hemophilia, World Bleeding Diosrder Registry, Data Report 2018. 